\title{
Lack of Microbial Diversity in an Extreme Mars Analog Setting: Poás Volcano, Costa Rica
}

\author{
Brian M. Hynek,, ${ }^{1,2}$ Karyn L. Rogers, Monique Antunovich, \\ Geoffroy Avard, and Guillermo E. Alvarado ${ }^{5}$
}

\begin{abstract}
The Poás volcano in Costa Rica has been studied as a Mars geochemical analog environment, since both the style of hydrothermal alteration present and the alteration mineralogy are consistent with Mars' relict hydrothermal systems. The site hosts an active volcano, with high-temperature fumaroles (up to $980^{\circ} \mathrm{C}$ ) and an ultra-acidic lake. This lake, Laguna Caliente, is one of the most dynamic environments on Earth, with frequent phreatic eruptions, temperatures ranging from near-ambient to almost boiling, a $\mathrm{pH}$ range of -1 to 1.5 , and a wide range of chemistries and redox potential. Martian acid-sulfate hydrothermal systems were likely similarly dynamic and equally challenging to life. The microbiology existing within Laguna Caliente was characterized for the first time, with sampling taking place in November, 2013. The diversity of the microbial community was surveyed via extraction of environmental DNA from fluid and sediment samples followed by Illumina sequencing of the $16 \mathrm{~S}$ rRNA gene. The microbial diversity was limited to a single species of the bacterial genus Acidiphilium. This organism likely gets its energy from oxidation of reduced sulfur in the lake, including elemental sulfur. Given Mars' propensity for sulfur and acid-sulfate environments, this type of organism is of significant interest to the search for past or present life on the Red Planet. Key Words: Mars astrobiology-Acid-sulfate hydrothermal systems-Extremophiles-Acidic-High temperature-Acidiphilium bacteria. Astrobiology 18, 923-933.
\end{abstract}

\section{Introduction and Motivation}

D UE TO THE PREVALENCE of both liquid water and volcanic activity early in Mars' history (e.g., Phillips et al., 2001; Hynek et al., 2010), it has been suggested that largescale hydrothermal alteration was a common process resulting in extensive deposits of acid-sulfate alteration minerals (e.g., Bibring et al., 2005; Solomon et al., 2005; Hynek et al., 2013). Indeed, Mars shows evidence of rampant volcanism and magmatism during the Noachian epoch $(>3.7 \mathrm{Ga})$ (e.g., Phillips et al., 2001; Carr and Head, 2010; Robbins et al., 2011), and this time period also exhibited extensive interaction of the crust with abundant surface waters that formed the valley networks (e.g., Hynek et al., 2010). Given the lack of plate tectonics on Mars, individual volcanoes had intermittent summit eruptions spanning nearly the entire 4 billion years of preserved geological history (Robbins et al., 2011). At these locales, condensation of volcanic vapors and hot springs would have provided localized warm and moist, albeit acidic, habitats for life even while cold and dry conditions persisted globally. Similarly, at least 78 large impact basins $(\geq 150 \mathrm{~km}$ diameter) formed prior to $\sim 3.5 \mathrm{Ga}$ (Robbins et al., 2013), and the larger ones likely hosted hydrothermal systems for up to 10 million years (Abramov and Kring, 2005). Given that widespread surface waters were episodic and limited in time, volcanic and impact systems may represent the most habitable niches for life on Mars through time and should be primary targets for astrobiological exploration.

Widespread relict hydrothermal systems have been identified on Mars' surface based on the observed mineralogy

\footnotetext{
${ }^{1}$ Laboratory for Atmospheric and Space Physics, University of Colorado, Boulder, Colorado, USA.

${ }^{2}$ Department of Geological Sciences, University of Colorado, Boulder, Colorado, USA.

${ }^{3}$ Earth and Environmental Sciences, Rensselaer Polytechnic Institute, Troy, New York, USA.

${ }^{4}$ OVSICORI, National University of Costa Rica, Heredia, Costa Rica.

${ }^{5}$ Centro de Investigaciones Geológicas, Red Sismológica Nacional, Universidad de Costa Rica, Costa Rica.
}

(C) Brian M. Hynek et al., 2018; Published by Mary Ann Liebert, Inc. This Open Access article is distributed under the terms of the Creative Commons Attribution Noncommercial License (http://creativecommons.org/licenses/by-nc/4.0/) which permits any noncommercial use, distribution, and reproduction in any medium, provided the original author(s) and the source are credited. 
and geomorphology data from orbiters and landers. The Spirit rover in Gusev crater detected sulfate and silica accumulations on the surface that suggest acid-sulfate alteration in fumarolic and/or hot spring environments next to a putative volcanic vent known as Home Plate (e.g., Squyres et al., 2007, 2008; Yen et al., 2008; Schmidt et al., 2009; Ruff et al., 2011). The large rift valley named Valles Marineris also shows mineral suites that include sulfates, hydrated silica, and phyllosilicates from putative regional-scale acid-sulfate hydrothermal alteration (Gendrin et al., 2005; Chojnacki and Hynek, 2008; Weitz et al., 2011; Thollot et al., 2012; Marcucci et al., 2013). Numerous volcanic edifices show morphological and mineralogical signs of hydrothermal activity. It has been hypothesized that radial valley networks on volcanic constructs formed via hydrothermal processes (Gulick, 1998, 2001; Tanaka et al., 1998; Dohm and Tanaka, 1999; Hynek et al., 2010; El Maarry et al., 2012). Although most martian volcanoes are currently covered in dust, preventing orbital observations of elemental and mineralogical composition, Skok et al. (2010) identified numerous hydrated silica deposits on the flanks of a volcanic cone in the Nili Patera caldera that they attributed to hydrothermal alteration. Finally, acidic hydrothermal alteration of basalt has been proposed as one possible explanation for the extensive sulfate deposits at Meridiani Planum (McCollom and Hynek, 2005, 2006).

Hydrothermal environments provide sources of heat, energy, and water for life (e.g., Walter and Des Marais, 1993; Schulze-Makuch et al., 2007; Hays et al., 2017) and may represent a unique habitable niche on Mars, past or present (MEPAG, 2015), as well as on early Earth. For example, it has been repeatedly hypothesized that the last universal common ancestor (LUCA) of life on Earth was a thermophile or hyperthermophile (e.g., Nisbet and Sleep, 2001; Di Giulio, 2003; Gaucher et al., 2008), likely capitalizing on iron-sulfur redox chemistry within hydrothermal settings (e.g., Martin and Russell, 2003; Wachtershauser, 2006; Martin et al., 2008; Weiss et al., 2016). It is conceivable that Mars experienced a similar history, making terrestrial hydrothermal systems with similar water-rock interactions ideal analogs to investigate Mars' habitability.

Inherent to water-rock reactions in hydrothermal systems are chemical disequilibria among redox-sensitive species, including those that are common in microbial metabolisms (e.g., $\mathrm{H}_{2} \mathrm{~S}, \mathrm{~S}^{0}, \mathrm{SO}_{4}{ }^{2-}, \mathrm{Fe}(\mathrm{II}), \mathrm{Fe}(\mathrm{III}), \mathrm{CO}_{2}, \mathrm{CO}, \mathrm{CH}_{4}$, and $\mathrm{H}_{2}$ ). In fact, most extant thermophiles are chemolithotrophs, exploiting these disequilibria to drive their metabolisms (e.g., Woese, 1987; Wachtershauser, 2006). In many hydrothermal systems on subaerial volcanoes, hot and acidic fluids arise either from interaction of magmatic gases with meteoric-derived waters or local steam condensates with abundant $\mathrm{SO}_{2}, \mathrm{SO}_{3}, \mathrm{H}_{2} \mathrm{~S}$, and $\mathrm{HCl}$. Moreover, when these systems host microbial communities, active mineralization of hydrothermal deposits such as silica sinter can encase and permineralize microbes to preserve a suite of textures, biofabrics, microfossils, and organic compounds (e.g., Hays et al., 2017). However, the dynamic nature of these environments often leads to a heterogeneous distribution of biosignatures that are vulnerable to oxidizing conditions that limit preservation of organic material.

Many of these acidic and sulfate-rich systems on Earth host thriving microbial ecosystems (e.g., Hedlund et al., 2016; Johnson and Aguilera, 2016). For example, Río Tinto,
Spain, often studied as a Mars analog, is an acidic (mean $\mathrm{pH}$ value 2.3) Fe-S system with a high concentration of heavy metals and high level of microbial diversity (e.g., Amils et al., 2007). While the microbial community is dominated by eukaryotes, both sulfur- and iron-oxidizing bacteria-such as Acidithiobacillus ferrooxidans, Acidithiobacillus thiooxidans, Leptospirillum spp., Acidiphilium spp.-were also present (e.g., González-Toril et al., 2003; Amils et al., 2007). In general, sulfur-dependent organisms span a range of environments and include thermophiles, hyperthermophiles, acidophiles, and neutrophiles. Furthermore, S-based metabolisms are ubiquitous throughout the tree of life and are quite diverse, taking advantage of the wide range of sulfur redox states ( -2 in $\mathrm{H}_{2} \mathrm{~S}$ to +6 in $\mathrm{SO}_{4}{ }^{2-}$ ) (Amend et al., 2004). Sulfur-dependent microbes thriving in acidic hydrothermal systems must be adapted to both high temperatures, which can denature proteins and nucleic acids (e.g., Rothschild and Mancinelli, 2001), as well as low pH, which is often neutralized in the cytoplasm by highly efficient proton pumps (e.g., Johnson and Aguilera, 2016). Among the S-dependent microbes commonly found in acidic hydrothermal environments on Earth are members of Acidianus, Acidithiobacillus, and Sulfolobus (e.g., Johnson and Aguilera, 2016). Despite the apparently harsh conditions, modern acid-sulfate hydrothermal systems on Earth host a wide variety of microbial communities adapted to these conditions, suggesting that similar relict martian systems could have also provided habitable niches across the planet throughout its history.

With this in mind, understanding the habitability at Mars' hydrothermal acid-sulfate systems is paramount to understanding the Red Planet's astrobiological potential through time. One commonly used method for assessing Mars' habitability is the study of Mars analog environments on Earth that replicate the chemistries, environmental conditions, and mineralogies inferred for the martian examples. One Marsrelevant analog representing hydrothermal acid-sulfate alteration in a volcanic setting is Poás volcano, Costa Rica. The active summit crater hosts fumarole fields and a warm to hot lake called Laguna Caliente. Poás volcano has previously been used as a model of planetary volcanism either to compare it with the scarps around the Olympus Mons volcano (Borgia et al., 1990) or to compare its sulfur-rich eruptions with those of Jupiter's moon Io (Oppenheimer and Stevenson, 1989; Oppenheimer, 1992). This volcanic crater has also been studied as a Mars geochemical analog, based on the similarities between alteration minerals and the inferred geochemical pathways of hydrothermal alteration at Poás and on Mars (Hynek et al., 2014; Black et al., 2015, 2016; Rodríguez and van Bergen, 2015, 2017; Black and Hynek, 2017). However, the microbiology of the lake system had never been detailed. It is also an end-member extreme environment (in terms of ultra-acidity and widely varying temperature and chemistry; see Section 2) that allows us to test the limits of life. Here, we present results of a microbial community profile within Poás' Laguna Caliente from a field excursion in November 2013 and discuss the implications for similar settings on ancient Mars.

\section{Poás Volcano and Laguna Caliente}

The Poás volcano is a structurally complex, basaltic andesite stratovolcano (Prosser and Carr, 1987) centered at 

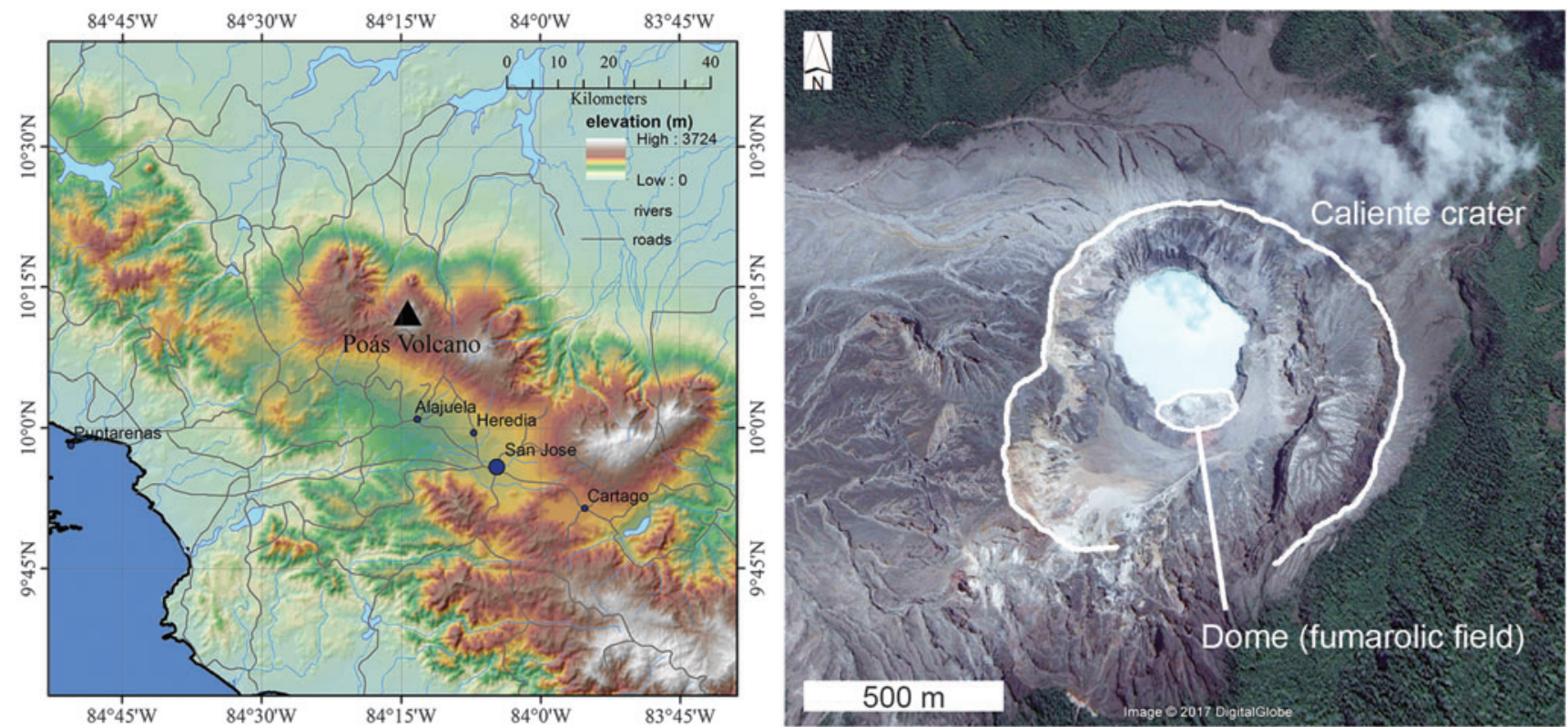

FIG. 1. (left) Location map of central Costa Rica and Poás volcano. (right) Google Earth image of Laguna Caliente and surrounding features of interest. Note the lack of vegetation to the west of the crater due to volcanic emissions and dominant easterly winds.

$10^{\circ} 11^{\prime} 49.36^{\prime \prime} \mathrm{N}, 84^{\circ} 13^{\prime} 47.19^{\prime \prime} \mathrm{W}$ in the Central Cordillera of Costa Rica (Fig. 1). The elevation of the active crater rim at the tourist lookout is 2575 meters above sea level (m.a.s.1.), but the general crater rim is at about 2450 m.a.s.l., with the active crater lake $130 \mathrm{~m}$ below. Unaltered Poás andesitic basalts collected in this study from the 1953-1955 magmatic activity are primarily composed of plagioclase, with minor orthopyroxene and olivine, and are compositionally similar to Thermal Emission Spectrometer (TES) measurements of the martian surface (McSween et al., 2009; Black and Hynek, 2017). The most recent eruptive period at Poás has occurred throughout the Holocene (Prosser and Carr, 1987), and the volcano has been active through historical times with significant eruptions in 1834, 1910, 1953-1955, and 2017 (ongoing at the time of this writing). These involved vulcanian and strombolian activity, phreatic to phreatomagmatic eruptions, and occasional lava flows (Prosser and Carr, 1987; de Moor et al., 2016). The phreatic to phreatomagmatic eruptions are common even during times of otherwise quiescence and include mostly unpredictable geyserlike expulsions from the crater lake, although recent efforts for prediction have improved (de Moor et al., 2016). The interval between these events can be hours to years and can send ash, lake mud, and elemental sulfur hundreds of meters into the air. The last phreatic eruption prior to our November 20, 2013, sampling of the crater occurred on June 3,2013 , and included a $\mathrm{SO}_{2}$-rich gas plume that rose $1 \mathrm{~km}$ above the crater (Global Volcanism Project, 2013). The ongoing magmatic eruptive phase began in April 2017 and has been of styles very similar to surtseyan, vulcanian, and strombolian eruptions.

Laguna Caliente is an extremely dynamic, ultra-acidic, ambient to hot lake in the active Poás crater (Fig. 2). A shallow magma body ( $\sim 500 \mathrm{~m}$ depth) (Rymer and Brown, 1989; Rymer et al., 2000) and associated rising magma dendrites and magmatic gases interact with meteoric and lake water at very shallow depths (Rymer et al., 2000), leading to the frequent phreatic activity. Lake chemistry is highly variable and controlled by both input and dissolution/ hydrolysis of magmatic volatiles and partial to wholesale dissolution of rock, enriching the lake in rock-forming elements (Rowe et al., 1992). Volcanic gases ( $\mathrm{HCl}$ and $\mathrm{H}_{2} \mathrm{~S}$ and $\mathrm{SO}_{2}$, which hydrolyze to $\mathrm{H}_{2} \mathrm{SO}_{4}$ ) contribute to the extreme acidity of the lake with $\mathrm{pH}$ through time ranging from -1 to 1.5 (Table 1). Times of higher lake temperature and lower $\mathrm{pH}$ lead to increased contribution from $\mathrm{HCl}$ and $\mathrm{SO}_{2}$ relative to $\mathrm{H}_{2} \mathrm{~S}$ (Rowe et al., 1992). Fluctuations in lake water temperature measured over decades range from $\sim 19^{\circ} \mathrm{C}$ to $96^{\circ} \mathrm{C}$, and total dissolved solids spanned a few to hundreds of grams per kilogram (Table 1) (e.g., Rowe et al., 1992). Higher temperatures and acidity also correlate with higher dissolved ion concentrations in the lake fluid (Table 1). The color of the lake ranges from bluish green, when ferrous iron concentration is higher in the lake waters due to increased injection of $\mathrm{H}_{2} \mathrm{~S}$, to yellow, when more $\mathrm{SO}_{2}$ is added and/or elemental sulfur is actively entrained in lake convection cells. Additionally, the lake volume changes drastically due to meteoric fluctuations and, more importantly, volcanic activity. The lake has had an estimated maximum volume of $>1 \mathrm{~km}^{3}$ but was also entirely drained in 1953 and 1989 (Oppenheimer and Stevenson, 1989; Rowe et al., 1992; Rymer et al., 2000). Images from July 14, 2017, show that the lake has once again disappeared. At the lake bottom exists a molten elemental sulfur deposit up to a few meters thick (e.g., Oppenheimer and Stevenson, 1989; Rowe, 1994); this is the source of the sulfur roiling in the lake's convective cells. Some of this elemental sulfur often floats as a froth on the lake surface (Fig. 3).

Fumaroles have been active in discrete locales within the active crater throughout historical times. Since the 19531955 eruptions, fumarole activity has been concentrated mostly along the dome area, extending down to the lake shore and underneath the fluids. The dome was formed during the 


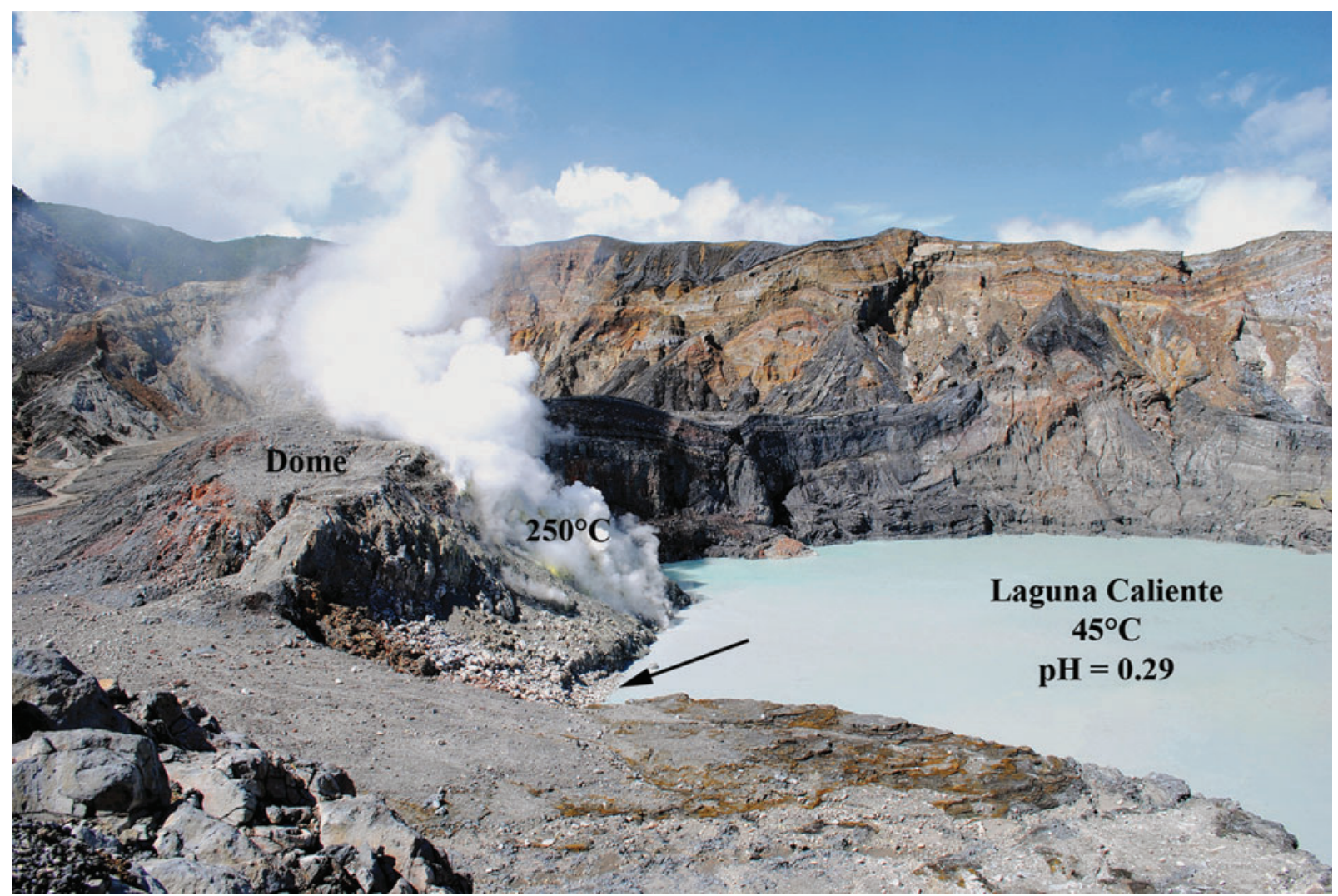

FIG. 2. The active Poás crater and Laguna Caliente. Arrow represents the biological sampling site.

1953 eruption when the lake had entirely drained (Rymer et al., 2000), and the majority of the cone has since been lost into the current crater lake during subsequent eruptions. The fumarole temperatures and gas composition have varied drastically through time in the dome area and rose to $900^{\circ} \mathrm{C}$ in 1981, implying that magma was just a few meters below the surface (Stevenson, 1993). Such an episode repeated in 2011. In April 2017, the dome area was entirely obliterated by ongoing eruptions.

These fumaroles have provided alteration minerals that are akin to a variety of relict hydrothermal sites on Mars (Hynek et al., 2014; Black et al., 2015, 2016; Rodríguez and van Bergen, 2015, 2017; Black and Hynek, 2017). The basaltic andesites alter rapidly in the high-temperature, ultra-acidic outgassing at fumaroles. The plagioclase minerals dissolve first in the parent rocks and combine with Fe from the orthopyroxenes and olivines to produce an abundance of natroalunite $\left(\mathrm{AlNa}_{3}\left(\mathrm{SO}_{4}\right)_{2}(\mathrm{OH})_{6}\right)$ and Fe-rich natroalunite, where $\mathrm{Fe}^{3+}$ replaces the $\mathrm{Al}^{3+}$ in the mineral formula. This mineral is a common alteration product in Mars analog experiments (McCollom et al., 2013; Marcucci and Hynek, 2014), in hydrothermal Mars analog field sites in Nicaragua and Iceland (Hynek et al., 2013, 2014; Marcucci et al., 2013; Black and Hynek, 2017), and in corollary geochemical models (McCollom et al., 2013; Marcucci and Hynek, 2014). McCollom et al. (2014) showed that jarosite and Fe-bearing natroalunite are indistinguishable in Mössbauer spectroscopy and that the jarosite detections on Mars by the Opportunity rover may in fact be Fe-bearing alunite. Jarosite is also a relatively common alteration product at Poás, as is gypsum, and these materials are both found in putative relict hydrothermal deposits on Mars (e.g., Squyres et al., 2008; Thollot et al., 2012; Marcucci et al., 2013). Нydrated silica is another common alteration mineral that is

Table 1. Laguna Caliente Fluid Sample Data from Historical Records and This Study

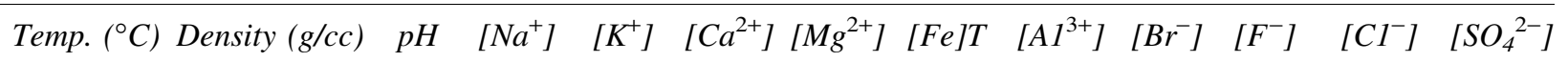

Summary of 39 Laguna Caliente fluid samples collected from 1980 to 1990 (Rowe et al., 1992)

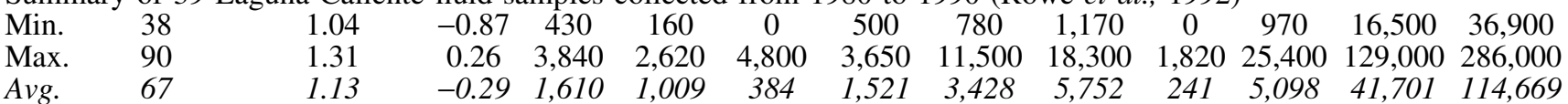

Fluid data from Laguna Caliente collected November 20, 2013, for this study

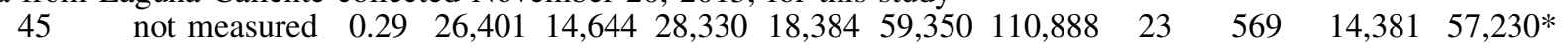

All concentrations are in $\mathrm{mg} / \mathrm{kg}$.

*Some of the sulfate reported in this sample is sulfite and also thiosulfate. 


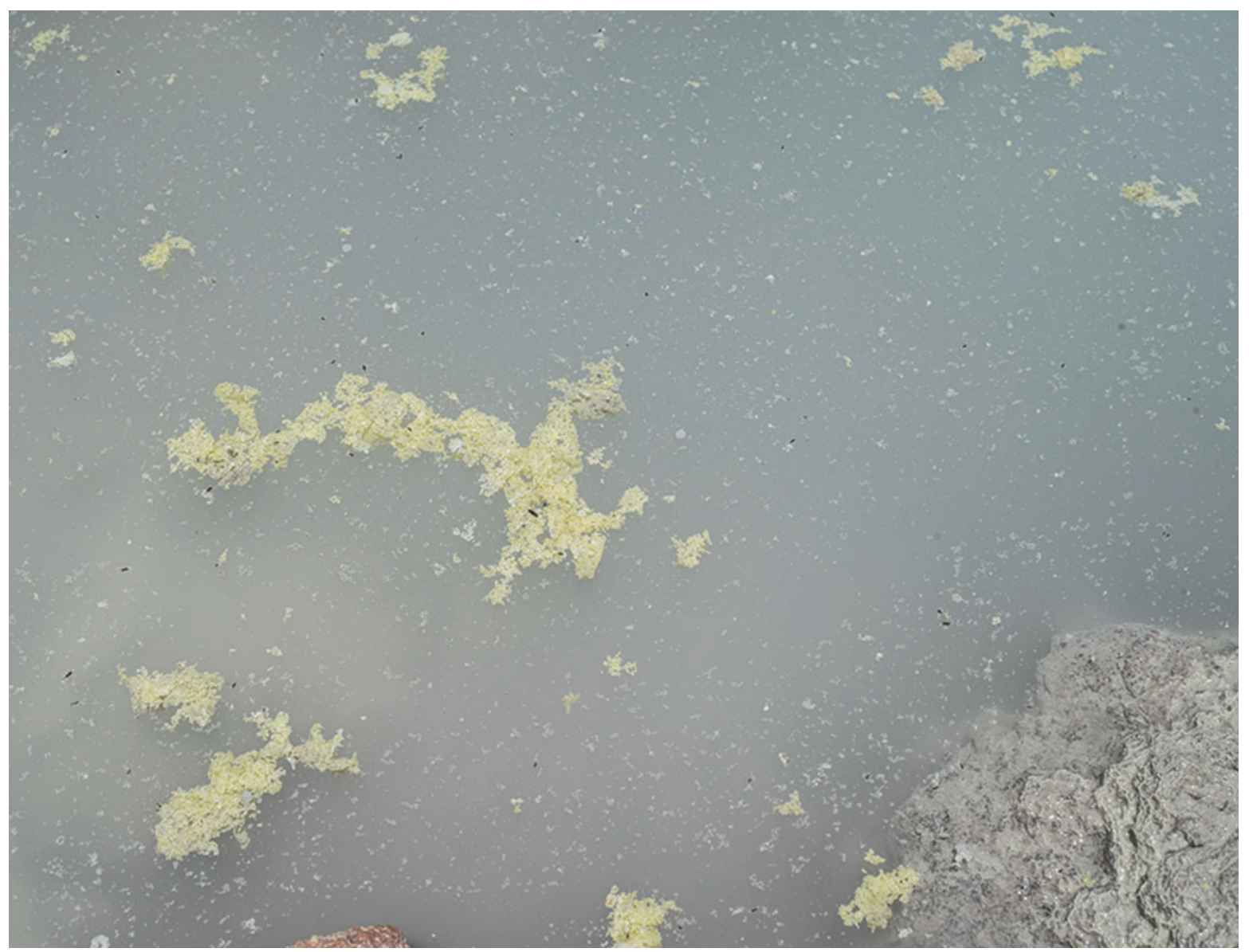

FIG. 3. Clumps of elemental sulfur floating on Laguna Caliente observed during the March 2017 field season. The longest clump is $\sim 6 \mathrm{~cm}$ in length.

widespread at Mars hydrothermal analog sites (e.g., Hynek et al., 2011, 2013, 2014) and on inferred similar paleoenvironments on Mars (e.g., Skok et al., 2010; Ehlmann et al., 2011; Ruff et al., 2011; Marcucci et al., 2013). The hightemperature silica phase of tridymite is also widespread around Poás fumaroles and was recently detected in Gale crater by the Curiosity rover (Morris et al., 2016). Dissolved Fe at Poás leads to abundant hematite and occasional goethite, which are common products across relict hydrothermal systems on Mars, such as within Gusev crater (e.g., Morris et al., 2005; Ming et al., 2008). Elemental sulfur is ubiquitous around the active fumaroles, forming large tabular crystals and occasionally solidified flow ribbons of previously molten sulfur. Collectively, the suite of alteration minerals at Poás crater and identified across Mars at relict hydrothermal sites shows strong correlation, indicating the high temperature and highly acidic geochemical processes occurring at Poás are quite relevant to understanding past hydrothermal processes on Mars.

\section{Laguna Caliente and Fumarole Characteristics during the November 20, 2013, Campaign}

During the 2013 sampling expedition, a broad area of the dome adjacent to Laguna Caliente was active with fumaroles (Fig. 2). The highest measured temperature was $\sim 250^{\circ} \mathrm{C}$, and fumarole condensates had a $\mathrm{pH}$ of -1 . The fumarole field extended from near the top of the dome down to and under the lake. $\mathrm{HCl}$ was present in the fumarolic gas along with the dominant $\mathrm{SO}_{2}$. Alteration minerals were collected and analyzed with XRD, XRF, VNIR spectroscopy, and Raman spectroscopy (Hynek et al., 2014; Black et al., 2016; Black and Hynek 2017), and general results are presented in Section 2. The lake muds at the location of biological sampling were analyzed with XRD, and mineralogy consisted predominately of elemental sulfur, moderate amounts of cristobalite, and minor amounts of alunite and tridymite.

The $\mathrm{pH}$ of the lake was 0.29 , and the temperature was $45^{\circ} \mathrm{C}$, relatively similar to long-term averages (Table 1). Lake fluids were collected in sterile Falcon tubes and then filtered through $0.2 \mu \mathrm{m}$ Sterivex filters and stored in the dark until analysis by ICP-MS and ICP-OES for cations, anions, and 62 additional element concentrations (Table 1). The highly acidic Poás lake waters showed very strong enrichment in the major cations (in decreasing abundance: $\mathrm{Al}^{3+}, \mathrm{Fe}(\mathrm{T}), \mathrm{Ca}^{2+}$, $\mathrm{Na}^{+}, \mathrm{Mg}^{2+}, \mathrm{K}^{+}$, and $\mathrm{Si}^{2+}$ ), with $\mathrm{Al}^{3+}$ at $>110,000 \mathrm{ppm}$ and $\mathrm{Si}^{2+}$ at $>6,000 \mathrm{ppm} . \mathrm{SO}_{4}{ }^{2-}$ and $\mathrm{Cl}^{-}$were the major anions, at $>57,000 \mathrm{ppm}$ and $>14,000 \mathrm{ppm}$, respectively. In addition to sulfate $\left(\mathrm{SO}_{4}{ }^{2-}\right)$, dissolved sulfite $\left(\mathrm{SO}_{3}{ }^{2-}\right)$ and thiosulfate $\left(\mathrm{S}_{2} \mathrm{O}_{3}{ }^{2-}\right)$ were also detected. Together with the elemental sulfur often seen floating in the lake, this large range of sulfur oxidation states represents a complex sulfur cycle that could provide a 
myriad of metabolic options for the wide variety of chemotrophic archaea and bacteria known to take advantage of sulfur redox chemistry in natural waters (e.g., Friedrich, 1997; Amend et al., 2004). Note that in our 2013 field campaign, no elemental sulfur was present on the lake surface, and thus it was not sampled directly, although on a recent trip in March 2017, abundant sulfur was observed floating on the lake's surface. The elemental sulfur is present as hollow spheres, up to a millimeter in size (allowing flotation), and XRD analysis shows $S^{0}$ is the only mineral present. Microbiology analyses of these sulfur clumps is ongoing.

\section{Microbiology Methods}

Lake fluid along with entrained sediment was collected aseptically in duplicate near the shore in sterile $50 \mathrm{~mL}$ Falcon tubes and immediately stored on water ice. These samples were frozen to $-4^{\circ} \mathrm{C}$ within hours and transferred to a $-80^{\circ} \mathrm{C}$ freezer within 4 days. DNA was extracted by using the MoBio PowerMax Soil kit following manufacturer's instructions. DNA from multiple extractions of the duplicate sample was pooled and concentrated with Amicon Ultra-4 spin filters (Millipore, Bellerica, MA). For sequence-based analyses of $16 \mathrm{~S}$ rRNA genes, we used the approaches described previously (Carini et al., 2016). The V4 region of the $16 \mathrm{~S}$ rRNA gene was PCR-amplified with barcoded primers (515F, 5'-GTGCCAGCMGCCGCGGTAA-3' and 806R, 5'GGACTACVSGGGTATCTAAT-3'; Caporaso et al., 2010). Products from duplicate PCR reactions for each sample, as well as "no template" and "DNA extraction" negative controls, were pooled, cleaned, and normalized with the ThermoFisher Scientific SequalPrep Normalization Plate kit, and sequenced on an Illumina MiSeq platform by using v2 500 -cycle paired-end kits in the Fierer Lab at CU Boulder.

Sequence reads were processed as previously described (Leff et al., 2015). Briefly, sequences were de-multiplexed, forward and reverse reads were merged, and quality-filtered with QIIME (Caporaso et al., 2010) and UPARSE (Edgar, 2013). A database of $\geq 97 \%$ similar sequence clusters was constructed in USEARCH (Version 8; Edgar, 2010) by merging paired end reads, using a "maxee" value of 0.5 when quality filtering sequences, de-replicating identical sequences, removing singleton sequences, clustering sequences after singleton removal, and filtering out cluster representative sequences that were not $\geq 75 \%$ similar to any sequence in the Greengenes database (for prokaryotes; Version 13_8) (McDonald et al., 2011). For the Laguna Caliente lake water and sediment sample, there was a total of 20,239 reads that passed quality filtering. De-multiplexed sequences were mapped against the de novo constructed databases to generate counts of sequences matching clusters (i.e., taxa) for each sample. Taxonomy was assigned to each taxon by using the RDP classifier with a threshold of 0.5 (Wang et al., 2007), trained on the Greengenes database, and sequences were aligned to known isolates with the BLASTn algorithm (Altschul et al., 1990) on the NCBI 16S rRNA database.

\section{Microbiology Results}

Taxonomy and distribution of the microbial population in the Laguna Caliente sample are shown in Table 2 and Fig. 4. Remarkably, across all the Laguna Caliente 16S rRNA gene reads, $\sim 98 \%$ of all the sequence reads clustered in a single operational taxonomic unit (OTU) within the genus Acidiphilium (Fig. 4 and Supplementary Material, available at http://online.liebertpub.com/suppl/doi/10.1089/ast.2017.1719). The remaining OTUs each represented $<0.5 \%$ of the sequenced amplicons and typically identified within the $\alpha$ Proteobacteria. The partial sequencing of the V4 region of the $16 \mathrm{~S}$ rDNA resulted in only 230 base pairs to use for comparison to existing genomic databases; thus a species-level identification is not possible. However, comparing the sequence of the dominant OTU (OTU 63) to known isolates using the BLASTn algorithm and the $16 \mathrm{~S}$ isolate database showed that this sequence was most closely related (100\% ID and $100 \%$ query coverage) to several species of Acidiphilium, including A. angustum, A. rubrum, and A. acidophilum (formerly Thiobacillus acidophilus [Guay and Silver, 1975; Hiraishi et al., 1998]) (see Table 2 and Supplementary Material).

Generally, members of the Acidiphilium genus are aerobic acidophilic bacteria, with several obligate heterotrophs and at least one facultative chemoautotroph (Harrison, 1981; Wichlacz et al., 1986; Dopson and Johnson, 2012). Most Acidiphilium species prefer $\mathrm{pH}$ from $\sim 1.5$ to 5.5 and temperatures ranging from $\sim 17^{\circ} \mathrm{C}$ to $45^{\circ} \mathrm{C}$ (Schippers, 2007), and members of this genus have been identified in and isolated from acid mine drainage (including the Mars analog

Table 2. Distribution and Taxonomy of OTUs Obtained from Laguna Caliente

\begin{tabular}{|c|c|c|c|c|c|c|c|}
\hline \multirow[b]{2}{*}{ OTU ID } & \multirow{2}{*}{$\begin{array}{c}\text { \# Quality } \\
\text { controlled } \\
\text { reads }\end{array}$} & \multirow{2}{*}{$\begin{array}{l}\% \text { of } \\
\text { total } \\
\text { reads }\end{array}$} & \multirow[b]{2}{*}{ Taxonomy (family/genus) } & \multicolumn{4}{|c|}{ BLAST alignment results } \\
\hline & & & & Type strain of top match & Accession \# & $\begin{array}{l}\text { Sequence } \\
I D\end{array}$ & $\begin{array}{l}\text { Sequence } \\
\text { coverage }\end{array}$ \\
\hline OTU 63 & 19,781 & 97.73 & Acetobacteraceae/Acidiphilium & $\begin{array}{l}\text { Acidiphilium angustum } \\
\text { strain KLB }\end{array}$ & NR 025850 & 100 & 100 \\
\hline OTU 2111 & 96 & 0.47 & Acetobacteraceae/Acidiphilium & $\begin{array}{l}\text { Acidiphilium multivorum } \\
\text { strain AIU301 }\end{array}$ & NR 074327 & 95.65 & 100 \\
\hline OTU 214 & 67 & 0.33 & Acidobacteraceae/NA & $\begin{array}{l}\text { Granulicella sapmiensis } \\
\text { strain S6CTX5A }\end{array}$ & NR 118023 & 98.81 & 100 \\
\hline OTU 5708 & 58 & 0.29 & Acetobacteraceae/Acidiphilium & $\begin{array}{l}\text { Acidiphilium angustum } \\
\text { strain KLB }\end{array}$ & NR 02580 & 96.84 & 100 \\
\hline OTU 2941 & 57 & 0.28 & Acidomicrobiaceae/NA & $\begin{array}{l}\text { Ferrimicrobium } \\
\text { acdiphilum strain } \mathrm{T} 23\end{array}$ & NR 041798 & 90.12 & 99 \\
\hline
\end{tabular}

Only OTUs with $>0.1 \%$ of the total reads are included. 


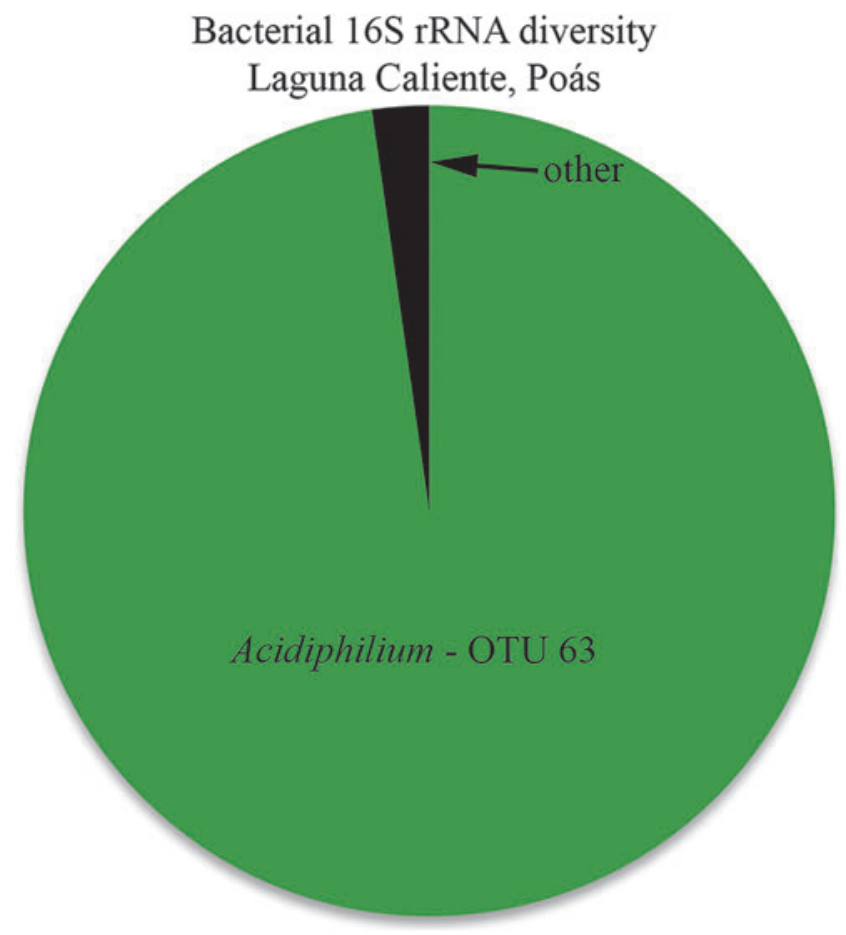

FIG. 4. Bacterial diversity at Laguna Caliente, Poás crater, Costa Rica. See text for details.

Río Tinto, Spain: González-Toril et al., 2003; Amils et al., 2007), with a limited number from hydrothermal environments and coal mine drainage (Harrison, 1981; Wichlacz et al., 1986; Lane et al., 1992; Kishimoto et al., 1995; Martin-Uriz et al., 2011). Several Acidiphilium species, including, A. rubrum, A. cryptum, and A. acidophilum, are known to oxidize elemental sulfur (and often other forms of reduced sulfur) for growth (Rohwerder and Sand, 2003; Rohwerder et al., 2003; Ghosh and Dam, 2009), and a number of isolates from this genus contain the soxXY$Z A B C D$ gene cluster, used in the well-known sox (sulfuroxidation) metabolic pathway for bacteria (Liu et al., 2016). Additionally, a number of the members of genus Acidiphilium are able to reduce Fe(III) (e.g., Lane et al., 1992; Küsel et al., 1999; Johnson et al., 2017).

\section{Discussion and Implications for Mars}

One of the most surprising aspects of our investigation was the remarkable, and nearly unprecedented, low diversity found in Laguna Caliente. With $98 \%$ of the amplicons falling within a single OTU, we argue that Laguna Caliente hosted a veritable monoculture (i.e., an ecosystem with very limited taxonomic diversity), at least at the time of sampling. Such occurrences of low diversity in natural ecosystem are quite rare. Even Iron Mountain, California, which hosts acid mine drainage with $\mathrm{pH}$ as low as -1.5 , contains much more diverse microbial communities that include all three domains of life (e.g., Edwards et al., 1999, 2000). Laguna Caliente is one of the most extreme habitats on our planet and may well represent the edge of the habitable range, likely due to the extremely low $\mathrm{pH}$, coupled to moderate but fluctuating temperatures and volcanic dy- namics, as well as very high concentrations of dissolved ions. Yet in our broad survey of Costa Rican hot springs as Mars analogs, we found one other monoculture at Borinquen Hot Springs source pool located on the side of the Rincón de la Vieja volcano (see Supplementary Material). Here, more moderate $\mathrm{pH}$ conditions, $\mathrm{pH}=4.8$, coupled with a much higher temperature, $\sim 92^{\circ} \mathrm{C}$, contribute to the limited habitability of this system. Thus, as shown by others (e.g., Rothschild and Mancinelli, 2001; Hedlund et al., 2016), temperature can be another important environmental variable in acid-sulfate hydrothermal systems. The microbial diversity was assessed at Borinquen following the methods described above. At this site, a hyperthermophilic archaeon was the sole representative in the thermal pool and was classified with the genus Pyrobaculum (see Supplementary Material). Members of this genus grow either chemolithoautotrophically by sulfur reduction or organotrophically by sulfur respiration.

Results of our taxonomic analysis strongly suggest that the species hosted in Laguna Caliente is a member of the genus Acidiphilium, which contains several isolates that exploit sulfur redox in their metabolism. The thermal conditions of the lake fall within the known tolerance of Acidiphilium species $\left(\sim 17-45^{\circ} \mathrm{C}\right)$; however, the reported $\mathrm{pH}$ tolerance of this genus $(\sim 1.5-6.5)$ (e.g., Schippers, $2007)$ is higher than that measured at the time of sampling (0.29) or in historical records (Table 1). Thus, it remains possible that Laguna Caliente at Poás volcano hosts a novel species of Acidiphilium that has a lower $\mathrm{pH}$ tolerance than other isolates within this genus. Nonetheless, the most closely related species within this genus can be used to infer potential metabolisms of the microbial population within the lake. Two of the most closely related species, $A$. acidophilum and A. rubrum, oxidize elemental sulfur and/or thiosulfate (e.g., Rohwerder and Sand, 2007), a metabolic strategy that is consistent with the conditions at Laguna Caliente, where there is an abundance of $\mathrm{S}^{0}$ and other reduced sulfur compounds (sulfite and thiosulfate) within the lake waters. The deepest phylogenetic branches of both Bacteria and Archaea include sulfur-based chemolithoautotrophic extremophiles (Woese, 1987; Fuchs et al., 1996). Russell and Hall (1997) used these data to argue that sulfur chemolithotrophy might have been the earliest selfsustaining metabolism. Others have argued that anaerobic iron oxidation might have supported Earth's earliest organisms (e.g., Russell and Hall, 1997; Martin et al., 2008). An iron-based metabolism is also consistent with our results, as some members of Acidiphilium, and many other acidophiles, are known to exploit Fe-based metabolisms (Lane et al., 1992; Küsel et al., 1999).

Mars likely did not have long-lived clement conditions or high-enough solar influx to develop photosynthesis. It is also likely that there were not abundant organic carbon sources, especially given the highly oxidizing atmosphere through most of its time. Thus, chemolithoautotrophic organisms might have been some of the first to appear on Mars (and Earth) and had the ability to be sustained. Given the abundance of $\mathrm{Fe}$ and $\mathrm{S}$ on the martian surface, and the preponderance of evidence supporting acid-sulfate alteration in volcanic hydrothermal systems, microbes like the one species in Laguna Caliente are perhaps the type of organism we should search for in future astrobiological missions to Mars. 
The Poás crater lake environment is immensely dynamic, ultra-acidic, and exhibits rapid changes in water volume, chemistry, and temperature (from near ambient to near boiling). Given the challenges for sustained, habitable environments on Mars through time, it is this level of diversity we might expect. From the abundance of jarosite and other sulfates found on the surface, combined with desiccation/ freezing to concentrate salts and widespread volcanic activity, it is hypothesized that many of the habitable niches at Mars' surface through time were of low $\mathrm{pH}$, moderate to high temperature, and highly dynamic. The mineralogy and geochemical processes occurring at Poás volcano are quite similar to Mars (as seen in the resultant alteration mineralogy: Hynek et al., 2014; Black et al., 2015, 2016; Rodríguez and van Bergen, 2015, 2017; Black and Hynek, 2017). The geochemical parameters and environmental conditions are also similar to many of the hydrothermal environments inferred for Mars, which, as argued above, may represent the most habitable niches through time on Mars. Given the chemical makeup of Mars (Fe and S enrichments) and the prevalence of early hydrothermal systems, deeply rooted, sulfur- (and $\mathrm{Fe}-$ ) oxidizing bacteria and archaea are perhaps the most likely organisms that would have originated and evolved on Mars. The characteristics of these microbes deserve further scrutiny, which will aid in the search for life on the Red Planet.

\section{Acknowledgments}

We thank the Noah Fierer lab at CU for DNA sequencing, post-processing, and scientific discussions. We also appreciate assistance from the Alexis Templeton lab at CU for use of facilities and scientific input. This work was supported by NASA Early Career Award \# NNX12AF20G, NASAMDAP \# NNX14AG90G, and the University of Colorado Center for the Study of Origins.

\section{Disclosures}

No competing financial interests exist.

\section{References}

Abramov, O. and Kring, D.A. (2005) Impact-induced hydrothermal activity on early Mars. J Geophys Res: Planets 110, doi:10.1029/2005JE002453.

Altschul, S.F., Gish, W., Miller, W., Myers, E.W., and Lipman, D.J. (1990) Basic local alignment search tool. J Mol Biol 215: 403-410.

Amend, J.P., Rogers, K.L., and D’Arcy, R. (2004) Microbially mediated sulfur-redox: energetics in marine hydrothermal vent systems. Geological Society of America Special Papers 379:17-34.

Amils, R., González-Toril, E., Fernández-Remolar, D., Gómez, F., Aguilera, Á., Rodríguez, N., Malki, M., García-Moyano, A., Fairén, A.G., de la Fuente, V., and Sanz, J.L. (2007) Extreme environments as Mars terrestrial analogs: the Río Tinto case. Planet Space Sci 55:370-381.

Bibring, J.P., Langevin, Y., Gendrin, A., Gondet, B., Poulet, F., Berthé, M., Soufflot, A., Arvidson, R., Mangold, N., Mustard, J., and Drossart, P. (2005) Mars surface diversity as revealed by the OMEGA/Mars Express observations. Science 307:1576-1581.

Black, S.R. and Hynek, B.M. (2018) Characterization of terrestrial hydrothermal alteration products with Mars analog instru- mentation: implications for current and future rover investigations. Icarus, 307:235-259.

Black, S.R., Hynek, B.M., and Alvarado, G.E. (2015) Spectral identification of acid sulfate alteration products in Costa Rica volcanoes: implications for early Mars [abstract 2260]. In $46^{\text {th }}$ Lunar and Planetary Science Conference, Lunar and Planetary Institute, Houston, LPI Contribution No. 1832.

Black, S.R., Hynek, B.M., Hoover, R., Beckerman, L.G., and Alvarado, G.E. (2016) Characterization of hydrothermal alteration in Costa Rica: mineralogy, methodology, and implications for Mars [abstract 2546]. In $47^{\text {th }}$ Lunar and Planetary Science Conference, Lunar and Planetary Institute, Houston, LPI Contribution No. 1903.

Borgia, A., Burr, J., Montero, W., Morales, L.D., and Alvarado, G.E. (1990) Fault propagation folds induced by gravitational failure and slumping of the central Costa Rica Volcanic Range: implications for large terrestrial and martian volcanic edifices. J Geophys Res 95:14357-14382.

Caporaso, J.G., Kuczynski, J., Stombaugh, J., Bittinger, K., Bushman, F.D., Costello, E.K., Fierer, N., Peña, A.G., Goodrich, J.K., Gordon, J.I., and Huttley, G.A. (2010) QIIME allows analysis of high-throughput community sequencing data. Nat Methods 7:335-336.

Carini, P., Marsden, P.J., Leff, J.W., Morgan, E.E., Strickland, M.S., and Fierer, N. (2016) Relic DNA is abundant in soil and obscures estimates of soil microbial diversity. Nat Microbiol 2, doi:10.1038/nmicrobiol.2016.242.

Carr, M.H. and Head, J.W. (2010) Geologic history of Mars. Earth Planet Sci Lett 294:185-203.

Chojnacki, M. and Hynek, B.M. (2008) Geological context of water-altered minerals in Valles Marineris, Mars. J Geophys Res: Planets 113, doi:10.1029/2007JE003070.

de Moor, J.M., Aiuppa, A., Pacheco, J., Avard, G., Kern, C., Liuzzo, M., Martínez, M., Giudice, G., and Fischer, T.P. (2016) Short-period volcanic gas precursors to phreatic eruptions: insights from Poás volcano, Costa Rica. Earth Planet Sci Lett 442:218-227.

Di Giulio, M. (2003) The universal ancestor and the ancestor of Bacteria were hyperthermophiles. J Mol Evol 57:721-730.

Dohm, J.M. and Tanaka, K.L. (1999) Geology of the Thaumasia region, Mars: plateau development, valley origins, and magmatic evolution. Planet Space Sci 47:411-431.

Dopson, M. and Johnson, D.B. (2012) Biodiversity, metabolism and applications of acidophilic sulfur-metabolizing microorganisms. Environ Microbiol 14:2620-2631.

Edgar, R.C. (2010) Search and clustering orders of magnitude faster than BLAST. Bioinformatics 26:2460-2461.

Edgar, R.C. (2013) UPARSE: highly accurate OTU sequences from microbial amplicon reads. Nat Methods 10:996-998.

Edwards, K.J., Goebel, B.M., Rodgers, T.M., Schrenk, M.O., Gihring, T.M., Cardona, M.M., Mcguire, M.M., Hamers, R.J., Pace, N.R., and Banfield, J.F. (1999) Geomicrobiology of pyrite $\left(\mathrm{FeS}_{2}\right)$ dissolution: case study at Iron Mountain, California. Geomicrobiol J 16:155-179.

Edwards, K.J., Bond, P.L., Druschel, G.K., McGuire, M.M., Hamers, R.J., and Banfield, J.F. (2000) Geochemical and biological aspects of sulfide mineral dissolution: lessons from Iron Mountain, California. Chem Geol 169:383-397.

Ehlmann, B.L., Mustard, J.F., Murchie, S.L., Bibring, J.-P., Meunier, A., Fraeman, A.A., and Langevin, Y. (2011) Subsurface water and clay mineral formation during the early history of Mars. Nature 479:53-60.

El Maarry, M.R., Dohm, J.M., Marzo, G.A., Fergason, R., Goetz, W., Heggy, E., Pack, A., and Markiewicz, W.J. (2012) 
Searching for evidence of hydrothermal activity at Apollinaris Mons, Mars. Icarus 217:297-314.

Friedrich, C.G. (1997) Physiology and genetics of sulfuroxidizing bacteria. Adv Microb Physiol 39:235-289.

Fuchs, T., Huber, H., Burggraf, S., and Stetter, K.O. (1996) 16S rDNA-based phylogeny of the archaeal order Sulfolobales and reclassification of Desulfurolobus ambivalens as Acidianus ambivalens comb. nov. Syst Appl Microbiol 19:56-60.

Gaucher, E.A., Govindarajan, S., and Ganesh, O.K. (2008) Palaeotemperature trend for Precambrian life inferred from resurrected proteins. Nature 451:704-707.

Gendrin, A., Mangold, N., Bibring, J.P., Langevin, Y., Gondet, B., Poulet, F., Bonello, G., Quantin, C., Mustard, J., Arvidson, R., and LeMouélic, S. (2005) Sulfates in martian layered terrains: the OMEGA/Mars Express view. Science 307:1587-1591.

Ghosh, W. and Dam, B. (2009) Biochemistry and molecular biology of lithotrophic sulfur oxidation by taxonomically and ecologically diverse bacteria and archaea. FEMS Microbiol Rev 33:999-1043.

Global Volcanism Project. (2013) Report on Poás (Costa Rica). Bulletin of the Global Volcanism Network, 38, doi:10.5479/ si.GVP.BGVN201309-345040.

González-Toril, E., Llobet-Brossa, E., Casamayor, E.O., Amann, R., and Amils, R. (2003) Microbial ecology of an extreme acidic environment, the Tinto River. Appl Environ Microbiol 69:4853-4865.

Guay, R. and Silver, M. (1975) Thiobacillus acidophilus sp. nov.; isolation and some physiological characteristics. Can J Microbiol 21:281-288.

Gulick, V.C. (1998) Magmatic intrusions and a hydrothermal origin for fluvial valleys on Mars. J Geophys Res 103:1936519387.

Gulick, V.C. (2001) Origin of the valley networks on Mars: a hydrological perspective. Geomorphology 37:241-268.

Harrison, A.P. (1981) Acidiphilium cryptum gen. nov., sp. nov., heterotrophic bacterium from acidic mineral environments. Int J Syst Bacteriol 31:327-332.

Hays, L.E., Graham, H.V., Des Marais, D.J., Hausrath, E.M., Horgan, B., McCollom, T.M., Parenteau, M.N., PotterMcIntyre, S.L., Williams, A.J., and Lynch, K.L. (2017) Biosignature preservation and detection in Mars analog environments. Astrobiology 17:363-400.

Hedlund, B., Thomas, S., Dodsworth, J., Zhang, C., and Miller, R. (2016) Life in high- temperature environments. In Manual of Environmental Microbiology, $4^{\text {th }}$ ed., edited by M. Yates, C. Nakatsu, R. Miller, and S. Pillai, ASM Press, Washington, DC, pp 4.3.4-1-4.3.4-15.

Hiraishi, A., Nagashima, K.V., Matsuura, K., Shimada, K., Takaichi, S., Wakao, N., and Katayama, Y. (1998) Phylogeny and photosynthetic features of Thiobacillus acidophilus and related acidophilic bacteria: its transfer to the genus Acidiphilium as Acidiphilium acidophilum comb. nov. Int J Syst Bacteriol 48:1389-1398.

Hynek, B.M., Beach, M., and Hoke, M.R.T. (2010) Updated global map of martian valley networks and implications for climate and hydrologic processes. J Geophys Res: Planets 115, doi:10.1029/2009JE003548.

Hynek, B.M., McCollom, T.M., and Rogers, K.L. (2011) Cerro Negro volcano, Nicaragua: an assessment of geological and potential biological systems on early Mars. Geological Society of America Special Papers 483:279-285.

Hynek, B.M., McCollom, T.M., Marcucci, E.C., Brugman, K., and Rogers, K.L. (2013) Assessment of environmental con- trols on acid-sulfate alteration at active volcanoes in Nicaragua: applications to relic hydrothermal systems on Mars. $J$ Geophys Res: Planets 118:2083-2104.

Hynek, B.M., McCollom, T.M., McHenry, L.J., and Alvarado, G.E. (2014) Assessing hydrothermal alteration on early Mars through analog environments in Nicaragua, Costa Rica, Iceland, and Hawaii [abstract 2172]. In $45^{\text {th }}$ Lunar and Planetary Science Conference, Lunar and Planetary Institute, Houston, LPI Contribution No. 1777.

Johnson, D.B. and Aguilera, A. (2016) The microbiology of extremely acidic environments. In Manual of Environmental Microbiology, $4^{\text {th }}$ ed., edited by M. Yates, C. Nakatsu, R. Miller, and S. Pillai, ASM Press, Washington, DC, pp 4.3.11-4.3.1-24.

Johnson, D.B., Hedrich, S., and Pakostova, E. (2017) Indirect redox transformations of iron, copper, and chromium catalyzed by extremely acidophilic bacteria. Front Microbiol 8, doi:10.3389/fmicb.2017.00211.

Kishimoto, N., Fukaya, F., Inagaki, K., Sugio, T., Tanaka, H., and Tano, T. (1995) Distribution of bacteriochlorophyll $a$ among aerobic and acidophilic bacteria and light-enhanced $\mathrm{CO}_{2}$-incorporation in Acidiphilium rubrum. FEMS Microbiol Ecol 16:291-296.

Küsel, K., Dorsch, T., Acker, G., and Stackebrandt, E. (1999) Microbial reduction of $\mathrm{Fe}(\mathrm{III})$ in acidic sediments: isolation of Acidiphilium cryptum JF-5 capable of coupling the reduction of $\mathrm{Fe}(\mathrm{III})$ to the oxidation of glucose. Appl Environ Microbiol 65:3633-3640.

Lane, D.J., Harrison, A.P., Stahl, D., Pace, B., Giovannoni, S.J., Olsen, G.J., and Pace, N.R. (1992) Evolutionary relationships among sulfur- and iron-oxidizing eubacteria. J Bacteriol 174: 269-278.

Leff, J.W., Jones, S.E., Prober, S.M., Barberán, A., Borer, E.T., Firn, J.L., Harpole, W.S., Hobbie, S.E., Hofmockel, K.S., Knops, J.M., and McCulley, R.L. (2015) Consistent responses of soil microbial communities to elevated nutrient inputs in grasslands across the globe. Proc Natl Acad Sci USA 112:10967-10972.

Liu, Y., Yang, H., Zhang, X., Xiao, Y., Guo, X., and Liu, X. (2016) Genomic analysis unravels reduced inorganic sulfur compound oxidation of heterotrophic acidophilic Acidicaldus sp. strain DX-1. Biomed Res Int 2016:1-8.

Marcucci, E. and Hynek, B. (2014) Laboratory simulations of acid-sulfate weathering under volcanic hydrothermal conditions: implications for early Mars. J Geophys Res: Planets 4: 679-703.

Marcucci, E.C., Hynek, B.M., Kierein-Young, K.S., and Rogers, K.L. (2013) Visible-near-infrared reflectance spectroscopy of volcanic acid-sulfate alteration in Nicaragua: analogs for early Mars. J Geophys Res: Planets 118:2213-2233.

Martin, W. and Russell, M.J. (2003) On the origins of cells: a hypothesis for the evolutionary transitions from abiotic geochemistry to chemoautotrophic prokaryotes, and from prokaryotes to nucleated cells. Philos Trans $R$ Soc Lond B Biol Sci 358:55-59.

Martin, W., Baross, J., Kelley, D., and Russell, M. (2008) Hydrothermal vents and the origin of life. Nat Rev Microbiol 6:805-814.

Martin-Uriz, P.S., Gomez, M.J., Arcas, A., Bargiela, R., and Amils, R. (2011) Draft genome sequence of the electricigen Acidiphilium sp. strain PM (DSM 24941). J Bacteriol 193: 5585-5586.

McCollom, T.M. and Hynek, B.M. (2005) A volcanic environment for bedrock diagenesis at Meridiani Planum on Mars. Nature 438:1129-1131. 
McCollom, T.M. and Hynek, B.M. (2006) Planetary science: bedrock formation at Meridiani Planum (Reply). Nature 443, doi:10.1038/nature05213.

McCollom, T.M., Robbins, M., Moskowitz, B., Berquõ, T.S., Jöns, N., and Hynek, B.M. (2013) Experimental study of acid-sulfate alteration of basalt and implications for sulfate deposits on Mars. J Geophys Res: Planets 118:577-614.

McCollom, T.M., Ehlmann, B.L., Wang, A., Hynek, B.M., Moskowitz, B., and Berquó, T.S. (2014) Detection of iron substitution in natroalunite-natrojarosite solid solutions and potential implications for Mars. Am Mineral 99:948-964.

McDonald, D., Price, M.N., Goodrich, J., Hawrocki, E.P., DeSantis, T.Z., Probst, A., Andersen, G.L., Knight, R., and Hugenholtz, P. (2011) An improved Greengenes taxonomy with 602 explicit ranks for ecological and evolutionary analyses of bacteria and archaea. ISME J 6:610-618.

McSween, H.Y., Taylor, G.J., and Wyatt, M.B. (2009) Elemental composition of the martian crust. Science 324: 736-739.

MEPAG. (2015) Mars Science Goals, Objectives, Investigations, and Priorities: 2015 Version, Mars Exploration Program Analysis Group (MEPAG), edited by V. Hamilton, white paper posted June 19, 2015, by the Mars Exploration Program Analysis Group. Available online at https://mepag .jpl.nasa.gov/reports/MEPAG Goals_Document_2015_v18_ FINAL.pdf

Ming, D.W., Gellert, R., Morris, R.V., Arvidson, R.E., Brueckner, J., Clark, B.C., Cohen, B.A., d'Uston, C., Economou, T., Fleischer, I., and Klingelhoefer, G. (2008) Geochemical properties of rocks and soils in Gusev Crater, Mars: results of the Alpha Particle X-Ray Spectrometer from Cumberland Ridge to Home Plate. J Geophys Res: Planets 113, doi:10.1029/2008JE003195.

Morris, R.V., Ming, D.W., Graff, T.G., Arvidson, R.E., Bell, J.F., Squyres, S.W., Mertzman, S.A., Gruener, J.E., Golden, D.C., Le, L., and Robinson, G.A. (2005) Hematite spherules in basaltic tephra altered under aqueous, acid-sulfate conditions on Mauna Kea volcano, Hawaii: possible clues for the occurrence of hematite-rich spherules in the Burns Formation at Meridiani Planum, Mars. Earth Planet Sci Lett 240:168-178.

Morris, R.V., Vaniman, D.T., Blake, D.F., Gellert, R., Chipera, S.J., Rampe, E.B., Ming, D.W., Morrison, S.M., Downs, R.T., Treiman, A.H., and Yen, A.S. (2016) Silicic volcanism on Mars evidenced by tridymite in high-SiO $\mathrm{S}_{2}$ sedimentary rock at Gale Crater. Proc Natl Acad Sci USA 113:7071-7076.

Nisbet, E.G. and Sleep, N.H. (2001) The habitat and nature of early life. Nature 409:1083-1091.

Oppenheimer, C. (1992) Sulphur eruptions at Volcán Poás, Costa Rica. Journal of Volcanology and Geothermal Research 49:1-21.

Oppenheimer, C. and Stevenson, D. (1989) Liquid sulphur lakes at Poás volcano. Nature 342:790-793.

Phillips, R.J., Zuber, M.T., Solomon, S.C., Golombek, M.P., Jakosky, B.M., Banerdt, W.B., Smith, D.E., Williams, R.M., Hynek, B.M., Aharonson, O., and Hauck, S.A., II. (2001) Ancient geodynamics and global-scale hydrology on Mars. Science 291:2587-2591.

Prosser, J.T. and Carr, M.J. (1987) Poás volcano, Costa Rica: geology of the summit region and spatial and temporal variations among the most recent lavas. Journal of Volcanology and Geothermal Research 33:131-146.

Robbins, S.J., Di Achille, G., and Hynek, B.M. (2011) The volcanic history of Mars: high-resolution crater-based studies of the calderas of 20 volcanoes. Icarus 211:1179-1203.
Robbins, S.J., Hynek, B.M., Lillis, R.J., and Bottke, W.F (2013) Large impact crater histories of Mars: the effect of different model crater age techniques. Icarus 225:173-184.

Rodríguez, A. and van Bergen, M.J. (2015) Volcanic hydrothermal systems as potential analogues of martian sulphaterich terrains. Netherlands Journal of Geosciences 95: 153-169.

Rodríguez, A. and van Bergen, M.J. (2017) Superficial alteration mineralogy in active volcanic systems: an example of Poás volcano, Costa Rica. Journal of Volcanology and Geothermal Research 345:54-80.

Rohwerder, T. and Sand, W. (2003) The sulfane sulfur of persulfides is the actual substrate of the sulfur-oxidizing enzymes from Acidithiobacillus and Acidiphilium spp. Microbiology 149:1699-1709.

Rohwerder, T. and Sand, W. (2007) Oxidation of inorganic sulfur compounds in acidophilic prokaryotes. Eng Life Sci 7: 301-309.

Rohwerder, T., Gehrke T., Kinzler K., and Sand W. (2003) Bioleaching review part A: Progress in bioleaching: fundamentals and mechanisms of bacterial metal sulfide oxidation. Appl Microbiol Biotechnol 63:239-248.

Rothschild, L.J. and Mancinelli, R.L. (2001) Life in extreme environments. Nature 409:1092-1101.

Rowe, G.L., Jr. (1994) Oxygen, hydrogen, and sulfur isotope systematics of the crater lake system of Poás volcano, Costa Rica. Geochem J 28:263-287.

Rowe, G.L., Jr., Brantley, S.L., Fernandez, M., Fernandez, J.F., Borgia, A., and Barquero, J. (1992) Fluid-volcano interaction in an active stratovolcano: the crater lake system of Poás volcano, Costa Rica. Journal of Volcanology and Geothermal Research 49:23-51.

Ruff, S.W., Farmer, J.D., Calvin, W.M., Herkenhoff, K.E., Johnson, J.R., Morris, R.V., Rice, M.S., Arvidson, R.E., Bell, J.F., Christensen, P.R., and Squyres, S.W. (2011) Characteristics, distribution, origin, and significance of opaline silica observed by the Spirit rover in Gusev Crater, Mars. J Geophys Res: Planets 116, doi:10.1029/2010JE003767.

Russell, M.J. and Hall, A.J. (1997) The emergence of life from iron monosulphide bubbles at a submarine hydrothermal redox and pH front. J Geol Soc London 154:377-402.

Rymer, H. and Brown, G. (1989) Gravity changes as a precursor to volcanic eruption at Poás volcano, Costa Rica. Nature 342: 902-905.

Rymer, H., Cassidy, J., Locke, C., Barboza, M., Barquero, J., Brenes, J., and Van der Laat, R. (2000) Geophysical studies of the recent 15-year eruptive cycle at Poás volcano, Costa Rica. Journal of Volcanology and Geothermal Research 97: 425-442.

Schippers, A. (2007) Microorganisms involved in bioleaching and nucleic acid-based molecular methods for their identification and quantification. In Microbial Processing of Metal Sulfides, edited by E.R. Donati and W. Sand, Springer, Dordrecht, the Netherlands, pp 3-33.

Schmidt, M.E., Farrand, W.H., Johnson, J.R., Schröder, C., Hurowitz, J.A., McCoy, T.J., Ruff, S.W., Arvidson, R.E., Des Marais, D.J., Lewis, K.W., and Ming, D.W. (2009) Spectral, mineralogical, and geochemical variations across Home Plate, Gusev Crater, Mars indicate high and low temperature alteration. Earth Planet Sci Lett 281:258-266.

Schulze-Makuch, D., Dohm, J.M., Fan, C., Fairen, A.G., Rodriguez, J.A.P., Baker, V.R., and Fink, W. (2007) Exploration of hydrothermal targets on Mars. Icarus 189: 308-324. 
Skok, J.R., Mustard, J.F., Ehlmann, B.L., Milliken, R.E., and Murchie, S.L. (2010) Silica deposits in the Nili Patera caldera on the Syrtis Major volcanic complex on Mars. Nat Geosci 3: 838-841.

Solomon, S.C., Aharonson, O., Aurnou, J.M., Banerdt, W.B., Carr, M.H., Dombard, A.J., Frey, H.V., Golombek, M.P., Hauck, S.A., Head, J.W., and Jakosky, B.M. (2005) New perspectives on ancient Mars. Science 307:1214-1220.

Squyres, S.W., Aharonson, O., Clark, B.C., Cohen, B.A., Crumpler, L., De Souza, P.A., Farrand, W.H., Gellert, R., Grant, J., Grotzinger, J.P., and Haldemann, A.F.C. (2007) Pyroclastic activity at Home Plate in Gusev Crater, Mars. Science 316:738-742.

Squyres, S.W., Arvidson, R.E., Ruff, S., Gellert, R., Morris, R.V., Ming, D.W., Crumpler, L., Farmer, J.D., Des Marais, D.J., Yen, A., and McLennan, S.M. (2008) Detection of silica-rich deposits on Mars. Science 320:1063-1067.

Stevenson, D.S. (1993) Physical models of fumarolic flow. Journal of Volcanology and Geothermal Research 57:139-156.

Tanaka, K.L., Dohm, J.M., Lias, J.H., and Hare, T.M. (1998) Erosional valleys in the Thaumasia region of Mars: hydrothermal and seismic origins. J Geophys Res 103:31407-31419.

Thollot, P., Mangold, N., Ansan, V., Le Mouelic, S., Milliken, R.E., Bishop, J.L., Weitz, C.M., Roach, L.H., Mustard, J.F., and Murchie, S.L (2012) Most Mars minerals in a nutshell: various alteration phases formed in a single environment in Noctis Labyrinthus. J Geophys Res: Planets 117, doi: 10.1029/2011JE004028.

Wachtershauser, G. (2006) From volcanic origins of chemoautotrophic life to Bacteria, Archaea and Eukarya. Philos Trans $R$ Soc Lond B Biol Sci 361:1787-1808.

Walter, M.R. and Des Marais, D.J. (1993) Preservation of biological information in thermal spring deposits: developing a strategy for the search for fossil life on Mars. Icarus 101:129-143.

Wang, Q., Garrity, G.M., Tiedje, J.M., and Cole, J.R. (2007) Naive Bayesian classifier for rapid assignment of rRNA sequences into the new bacterial taxonomy. Appl Environ Microbiol 73:5261-5267.
Weiss, M.C., Sousa, F.L., Mrnjavac, N., Neukirchen, S., Roettger, M., Nelson-sathi, S., and Martin, W.F. (2016) The physiology and habitat of the last universal common ancestor. Nat Microbiol 1:1-8.

Weitz, C.M., Bishop, J.L., Thollot, P., Mangold, N., and Roach, L.H. (2011) Diverse mineralogies in two troughs of Noctis Labyrinthus, Mars. Geology 39:899-902.

Wichlacz, P.L., Unz, R.F., and Langworthy, T.A. (1986) Acidiphilium angustum sp. nov., Acidiphilium facilis sp. nov., and Acidiphilium rubrum sp. nov.: acidophilic heterotrophic bacteria isolated from acidic coal mine drainage. Int J Syst Bacteriol 36:197-201.

Woese, C.R. (1987) Bacterial evolution. Microbiol Rev 51: 221-271.

Yen, A.S., Morris, R.V., Clark, B.C., Gellert, R., Knudson, A.T., Squyres, S., Mittlefehldt, D.W., Ming, D.W., Arvidson, R., McCoy, T., and Schmidt, M. (2008) Hydrothermal processes at Gusev Crater: an evaluation of Paso Robles class soils. J Geophys Res: Planets 113, doi:10.1029/ 2007JE002978.

Address correspondence to:

Brian M. Hynek Laboratory for Atmospheric and Space Physics

University of Colorado 3665 Discovery Dr. Boulder, CO 80303

E-mail: hynek@lasp.colorado.edu

Submitted 18 July 2017 Accepted 4 January 2018

\section{Abbreviation Used}

$\mathrm{OTU}=$ operational taxonomic unit 